\title{
Industrial Policies in France: The Old and the New
}

\author{
Elie Cohen
}

Received: 15 November 2006 / Revised: 25 December 2006 /

Accepted: 2 February 2007 / Published online: 24 July 2007

(C) Springer Science + Business Media, LLC 2007

\begin{abstract}
Industrial policy is mainly sector based in France, moulding industrial specialization and often promoting "grand projects." It intended to make use of economies of scale, specifically in technologically sophisticated sectors and has been labelled as High Tech Colbertism. The European unification and the Single Market Programme has to some extent converted European industrial policy to the horizontal approach, banning sectoral activities, promoting framework policies, and a sound macro economic policy. The Lisbon strategy then designed a new agenda for growth which acknowledged a gap in competitiveness relative to the USA. In France new initiatives were launched in the past decade, which to some extent are echoing the French type of industrial policy. Regional cluster programs ("poles de competitivité") were introduced, an industrial innovation agency and a national research agency were founded and the Oseo program promotes small and medium firms. The history, preconditions and chances of the new initiatives are analysed.
\end{abstract}

Keywords industrial policy $\cdot$ clusters $\cdot$ single market

JEL Classification $\mathrm{D} 78 \cdot \mathrm{G} 28 \cdot \mathrm{L} 50 \cdot \mathrm{L} 52 \cdot \mathrm{O} 33$

Since 1945 the debate about industrial policy has been particularly intense on three main occasions. The first, under General de Gaulle, was when two conflicting policies of reconstruction and catch up vis-à-vis the USA were at stake. One method was driven by the market and regulated by the German institutional social compromise, while the other was powered by the State, managed finance and public sector firms. This first debate will loose its acuity with the end of the "Thirty Glorious years" and the subsequent crises of the 1970s.

With the emergence of Japan as a manufacturing super-power in the first half of the 1980s, industrial policy discourse regain influence both in Europe and in the USA. The export led growth model designed by Japan officials and managed by Miti, ${ }^{1}$ which mitigates the

\footnotetext{
${ }^{1}$ The Japanese Ministry of Industry and Foreign Trade.

E. Cohen $(\bowtie)$

SciencesPo CNRS, 98, rue de l'Université, 75007 Paris, France

e-mail: elie.cohen@wanadoo.fr
} 
benefits of openness on the world market and partial closure within domestic market took center stage. By disputing its unwarranted advantages, Europeans and Americans intended to protect those businesses at risk by implementing agreements of voluntary restrictions on exports (such as automobiles) and by promoting their leading industries.

With the creation of the single European market, the tremendous decade of growth in the USA and the Japanese lost decade, industrial policies seemed to have disappeared entirely from the political landscape. In the last several months, however, industrial policies have made a comeback in response to the first perceived effects of outsourcing and the growing power of China. In Brussels, a new interest is manifest, due to the fact that competitive environmental policies didn't deliver in terms of specialization and growth. If the same concept is resurfacing in the present, does it necessarily refer to the same realities of the past?

In order to evaluate industrial policies, one must first define the concept. In France, this notion is used mainly for sector-based policies in the manufacturing industry: those that mould industrial specialization. Elsewhere, the notion of industry itself is broader, as one speaks indifferently of financial or manufacturing industries and the scope of policies is both horizontal and vertical. Consequently, the concept of industrial policies is more extensive as one combines, under the same label, commercial, technological and competitive policies.

\section{What is industrial policy?}

Industrial policy has never given rise to a specific theoretical corpus, despite the fact that foundations for such a corpus have existed since List and Hamilton, and history has taught us that the visible hand of the state has played a significant role every time an economy has taken off. Economists have often taken part in debates on industrial policy by applying some aspect or another of the discipline or by debating the effectiveness and the legitimacy of government action. But they have rarely undertaken the empirical work needed to confirm their theoretical assumptions.

Neoclassical theory accepts industrial policy measures only where the market allocates resources inefficiently. This has inspired a body of literature on market failures. Ever since public intervention has flourished in adjustment policies and in prompting and protecting infant industries, a new sphere emerged dealing with the state's failures and the impasse confronting the "national champions" policies. However, in the 1980s, a number of economists attempted to establish a theoretical foundation for public intervention by borrowing from a variety of advances in economics such as evolutionary theories of economic change, new trade theory, and new economic geography. More recent advances in new development and growth theories gave rise to more pragmatic views on industrial policies. ${ }^{2}$

In this paper we contrast competitive environmental policies that have an indirect impact on industry-including macroeconomic and social policies, as well as infrastructure and national defense policies - and vertical industrial policies which are sector-targeted policies and which seek to promote sectors in which state intervention take place for reasons of national independence, technological autonomy, failure of private initiative, decline in traditional activities, and geographical balance.

According to this perspective, competition policy has a different aim, namely the prohibition of dominant positions, market abuses, and regulation of state aids. Trade policy tends to promote the free movement of goods and services based on the theory of comparative

\footnotetext{
${ }^{2}$ See Cohen (2006).

嫼 Springer
} 
advantage in order to maximize social welfare. $R \& D$ or Technology policy tends to create positive externalities for the whole economy.

These delineations, based on the specificity of each tool of intervention, are not that simple in the real world. In fact these different policies have the potential of producing tremendous impacts on industry even on a sector-based level. Historically these tools were used specifically (or in conjunction with other tools) to obtain desirable industrial outcomes. Depending on the country variety of capitalism, any existing sector-based policy is the responsibility either of the state (directly or indirectly), or public banks, or local authorities. For example, in the USA the real minister of Industry and High Technologies is in fact the Department of Defense. In Japan, industry has been protected by trade policy and certain sectors have been promoted through finance, currency allocations and support for large commercial undertakings. In Germany aid to businesses is essentially paid through the Länder under the auspices of technology policies, whilst it is the banks' responsibility to rescue businesses in difficulty.

Although vertical and horizontal policies may play the same role in different periods and countries, it is useful to make analytical distinctions because we need to understand why the apparent successes of certain policies are still contested and if there is more room for industrial policy in a globalized world.

\section{Industrial policies in France: the "colbertist model"}

A distinction between three situations must be made. The conditions under which the state intervenes and the status of "national champions" are in fact different depending on whether the state is faced with powerful industrial actors whose structures and strategies it hopes to influence, politically destabilizing lame ducks, or lastly if confronted by a complete absence of industrial actors in a sector seen as decisive for national independence, therefore becoming the most likely terrain for "grand projects." 3

In all three cases the means of intervention are formally comparable: sectoral plans, structural policies, direct subsidies or low-rate credits for modernization, investment, exports, etc. In practical terms, however, the effects of these tools have been radically different.

We will not assess the different French industrial policies from 1945 to 1984, if not to remind ourselves on the one hand that only very few industrial policies actually influenced specialization, among which one can count those policies inspired by high-tech Colbertism. And, on the other hand, it is important to rediscover the reasons for the French state's rejection of these industrial policies after 1984.

Since World War II, high-tech Colbertism has been the historical form used for the intervention of a sovereign nation state, armed with a monopoly of the general interest, in the so-called "industries of the future" (see Fig. 1). Five characteristics summarize this model and call into question preconceived ideas about French interventionism. They allow us to understand the process through which embryonic hybrids of administration and private companies transformed themselves from national champions into globalized firms.

1. Offensive protectionism is the first condition of the success of a "grand project." The sovereign state creates the means of accumulation of scientific and financial resources. It provides future national champions with grants, secures markets through public

\footnotetext{
${ }^{3}$ See Cohen and Bauer (1985), Cohen (1989, 1992).
} 


\begin{tabular}{|c|c|c|c|c|c|c|}
\hline Grand Project & $\begin{array}{l}\text { Public } \\
\text { Agency }\end{array}$ & Research la & \begin{tabular}{|c|} 
National \\
champion
\end{tabular} & Public Finance & Regulation body & $\begin{array}{l}\text { Public } \\
\text { procurement }\end{array}$ \\
\hline Oil Industry & ERAP & IFP & Elf & Fiscal devices & $\begin{array}{c}\text { Integrated } \\
\text { administrative } \\
\text { regulator IAR }\end{array}$ & $\begin{array}{l}\text { NO } \\
\text { Protection } \\
\text { YES }\end{array}$ \\
\hline $\begin{array}{c}\text { Nuke Power } \\
\text { generation }\end{array}$ & EdF & CEA & Areva & Debt guarantee & IAR & YES \\
\hline Civil Aircraft & DAC & ONERA & Aerospatiale & $\begin{array}{c}\text { Reimbursement } \\
\text { advances }\end{array}$ & IAR & YES \\
\hline \begin{tabular}{|l} 
Military \\
Aircraft
\end{tabular} & DGA & DGA & Dassault & Budget & IAR & YES \\
\hline Space & CNES & CNES & Arianespace & Budget & IAR & YES \\
\hline Telecom & $\begin{array}{l}\text { DGT } \\
\text { FT }\end{array}$ & CNET & Alcatel & Debt guarantee & IAR & YES \\
\hline Railway & SNCF & Alstom & Alstom & Debt guarantee & IAR & YES \\
\hline
\end{tabular}

Fig. 1 Overview on institutions involved in grand projects

procurement policies, and prevents foreign entry. The argument for doing so is always defense, national sovereignty and technological autonomy. But success in the international marketplace is the ultimate goal.

2. Innovation is not only scientific or technical in nature, even in situations where the initial technical paradigm has been transformed radically. Nuclear power generation, space industry, high speed trains, civil and military aeronautics and telecommunications all show that innovation is more important in bringing together different actors from different fields and make them accountable for the success of an important venture. Strict national technologies (graphite-gas in nuclear power, 'Diamant' for space exploration, 'Aerotrain' for the rail-ways, etc.) were all abandoned under pressure from industrialists and public service users in order to guarantee the collective aim and the success of the sector as a whole. This illustrates the capability even by state actors to kill white elephants.

3. The "grand project" is possible only within the framework of a flexible state. The hybrid administration-enterprise embodies two sides of a coin: tails, regalian authority, and heads, the logic of an enterprise (BRP for oil, CNES for space, DGT for telecommunications). The provision of financial support outside the annual budgetary procedures, for example through a medium-term program, and especially the use of public procurement for national industrial ends, supports this analysis.

4. The "grand project" attracts capitalism without capital. This certainly means that the State has the upper hand on the industrialists at the beginning, but once there is a move away from the State procurement logic, the latter are capable of freeing themselves. 
5. The "grand project" emerges only when the objectives of industry participants converge with those of overall policy. This explains the succession over time of long phases of underdevelopment followed by intense periods of intervention. Lastly, leaving aside the convenient abstraction of the State, the "grand project" takes off only when a homogeneous elite (trained in the "grandes écoles" and socialized in "cabinets ministeriels") is capable of mobilizing a workforce committed to the purposes of the state-entrepreneur and of national independence.

The "grand project" follows a sequence of logics: the 'arsenal' logic, ${ }^{4}$ the logic of public procurement, and the logic of the market which, when completed, enriches the national productive system with new, powerful actors who are sometimes rivals (with conflicts between technical agency, user, and industrialist). It is based upon a technological challenge. It is promoted by an agency that may be specifically created for this purpose. Its success therefore depends on a transfer of results and close cooperation with industry. This relationship is only entirely fruitful because the State promotes an aggressive protectionism, finances the early stages of industrial development, transfers the results of public research, provides certain markets through public procurement, allows the depreciation of investment over a long period, and encourages development by putting the State's powers at the service of the national champion, be it public or private.

The success of the "grand project" occurs when the State launches an investment program in infrastructures based upon the technologies developed by the "national champion" and when this champion succeeds in selling its products and services on international markets. The five pillars upon which the success of a "grand project" rests are: technical innovation, emergence of new patterns of consumption, dynamic protectionism, the rising of a new industrial participant, and socio-political engineering. The success of the "grand project" is the first source of its subsequent loss of attraction, since the national champions and the public service providers tend to prefer establishing themselves in the international market above any other consideration. Elf-Aquitaine (Total group), Arianespace, Alcatel, Alstom, France Télécom, EdF, Airbus Industrie (EADS), Snecma (Safran) : all of these are industrial or service companies born or nurtured by the national "grand project" and redeployed now on a European level. They base their new legitimacy upon the market. In fact, during the nurturing phase these national champions benefited from the discretionary power of the nation state. Once they created a competitive advantage by mastering a technology-such as nuclear power generation or achieving a high level of productivity (telecoms) or gaining market share (aeronautics) - these national champions began to see state intervention as a threat to their cash flow, to their own discretionary power and as an impediment to building international alliances. So the greater the success of the "grand project," the bolder the determination of globalized national champions to be freed from state dependence and to be judged according to market criteria.

One of the last identifiable "grand projects" is that of telecommunications, with the catchup plan dating from 1974. It is of the same period as the nuclear and railway plans, the first launched in 1969 and intensified in 1973, and the latter announced in 1976. However, in both cases, the period of "arsenal" logic, goes back the furthest. Since then, plans for "Telematics" (Minitel) satellites, and cable television have appeared, but have been added to the list of

\footnotetext{
${ }^{4}$ Arsenal means a place where weapons are made and stored under the direct control of the state. By "Arsenal logic" we mean an industrial logic where the state defines the program and the specs, choose the industrialist, finance the R\&D, the prototype, and even the line of production.
} 
white elephants rather than having given birth to powerful industries. Finally, the grand projects that have a national origin, such as Ariane, Airbus, or even the TGV, have become European. Of course, in each of these three cases, the technological and political initiator has been French. However, in order to succeed these projects have either become European or are in the process of so becoming (TGV Alstom $=-$ GEC + Alstom + Fiat).

The 'grand projects' described here were successful. But other voluntarist industrial policies led to major failures. One of the best examples was that of the "Plan Calcul."

- Regaining national independence in the high tech sector especially in computer industry was the key driver of 'Plan Calcul'. In so doing the French state pursued the same objectives than in aeronautics. But 'offensive protectionism' is impossible in this field because the main demand of computers is coming from the private sector.

- Nevertheless the French Government decided to create a new company 'Compagnie Internationale pour l'Informatique CII' and gave it a mission 'Conceive and build a powerful scientific computer free from any American technological input'. Clearly the 'Plan Calcul' meets the second condition of our model.

- The flexible State is quite present in the "Plan Calcul" since an Agency was created "La Delegation pour l'Informatique" whose aim was to build a new company with different private assets, to finance the new products of this company, and to force administrations to be equipped with CII products.

- The "grand project" attracts capitalism without capital. It is clearly the case of the "Plan Calcul'. But at this level a fault line appears. The private shareholders of CII decided to promote commercial computers (with proprietary standards) and not scientific computers designed for the military.

The last condition of the 'grand project' which is a huge procurement policy aimed at serving the national market was not met at all. The French State and its administration are marginal customers of computers compared to business users. CII thus could benefit neither from a large public market, nor of a national industrial development program financed by the State and CII was adversely confronted with a hard competition from IBM that the State did not want to limit.

CII failed because "offensive protectionism" was impossible, because computers are commercial products and the state is a buyer, it is not an infrastructure project. CII failed because although the State financed the whole project, private owners of CII had a different agenda.

This high tech Colbertism model ends its course at the beginning of the 1980s when the need of adaptation described above and external constraints collide. In fact in the new Europe of the single market, industrial policy has had to be redesigned at both the European and the national level. This "colbertist policy" was unanimously considered a success by the "French development party" (industrialists, civil servants, politicians and even trade unions): France experienced a tremendous growth in the post war years and transformed itself into an industrial powerhouse, the French specialization till today was heavily influenced by these sectoral original choices, the "national champions" succeeded too in their transformation into European globalized firms. ${ }^{5}$ Of course they were some drawbacks in these policies, certain major failures in the computer and the machine tool industry occurred, and one can say that we don't have counter-factual evidence, but on a whole this policy of state built competitive

\footnotetext{
${ }^{5}$ See Global Fortune 500, it is interesting to note that French based firms are third (38 firms in the top 500) and mainly from "grand projects" origin.
} 
advantage worked. ${ }^{6}$ In an appraisal of "national champions policy" and especially of the Airbus case Paul Seabright reach the same conclusions : this policy is at its best when it deals with large firms, hi-tech, low variety, large scale economies, dependent on commitment. "Governments are not necessarily worse at picking winners than markets are. But markets are much better at terminating projects that turn out to be unsuccessful. Recent research shows this is very important for productivity growth, more in some sectors than other. So National champions less suitable for, say, computers than aircraft."7

\section{A tentative European industrial policy}

At the beginning of the 1980s, a "Euro-pessimism" crisis spread through Europe. Numerous industrialists questioned the future of Europe in light of the nations' recurring monetary crisis, the latent economic crisis and the general feeling of economic decline. Various solutions were offered in response to the potential cost of a "non-Europe," the effects of neo-protectionism, and the industrial widening gap with Japan. Within this situation, the dysfunctions of the European machinery, the drawbacks of the rule of unanimity, and the Byzantine process of harmonization were also at stake. Sectors in difficulty like steel or shipbuilding industries followed a palliative policy as if the Community knew how to liquidate old industries, but no longer knew how to build new ones. Of course, the distress of ailing industries was accompanied by social and financial measures that permitted redevelopment of old company towns, personnel training and territorial provisions. Simultaneously, however, the fragmentation of the high tech industry and the redundancy of European research on information technologies crushed all hope of a significant development in these ever-expanding sectors. ${ }^{8}$ This awareness of Europe's institutional paralysis and industrial decline would not have had significant effects had Europe's geo-strategic position not been also in decline during this same period. Europe's political marginalization was brought to light by President Reagan's strategic initiative known as "Star Wars." At the same time a trade dispute strongly opposed the Japanese and the Americans. All of these initiatives had revealed Europe's risk of political marginalization and the potential cost to the prosperity of Europeans due to a prolonged and worsened division.

In this context European political leaders were compelled to make bold propositions, but how can one invent a solution that bridges interventionist and liberal solutions, supranational and intergovernmental solutions, domestic integration and expression of a European will on the world stage. The Single European Act (SEA) and the Maastricht Treaty were the answer.

The SEA was arranged politically by the reconstruction of the French-German alliance, institutionally by the program of " 300 " liberalization directives, and economically by various industrial initiatives born out of the awareness of European technological gap. ${ }^{10} \mathrm{Mr}$. Étienne Davignon, for example, had initiated the creation of a lobby of large industrial firms. The aim of the lobby was to identify and help with the problems related to the European

\footnotetext{
${ }^{6}$ Rodrik (2004) developed this line of analysis.

${ }^{7}$ Seabright (2005).

${ }^{8}$ On this European lethargy, see chapters 5, 6 and 7 of Richonnier (1985).

${ }^{9}$ President Mitterrand therefore invented "Eureka" a civil response to a threat deriving from heavy investments in US defense industries.

${ }^{10}$ The definitive break-through in terms of free circulation of goods and services was achieved by the induction of the Arrêt Cassis de Dijon, which permitted to end interminable procedures of harmonization.
} 


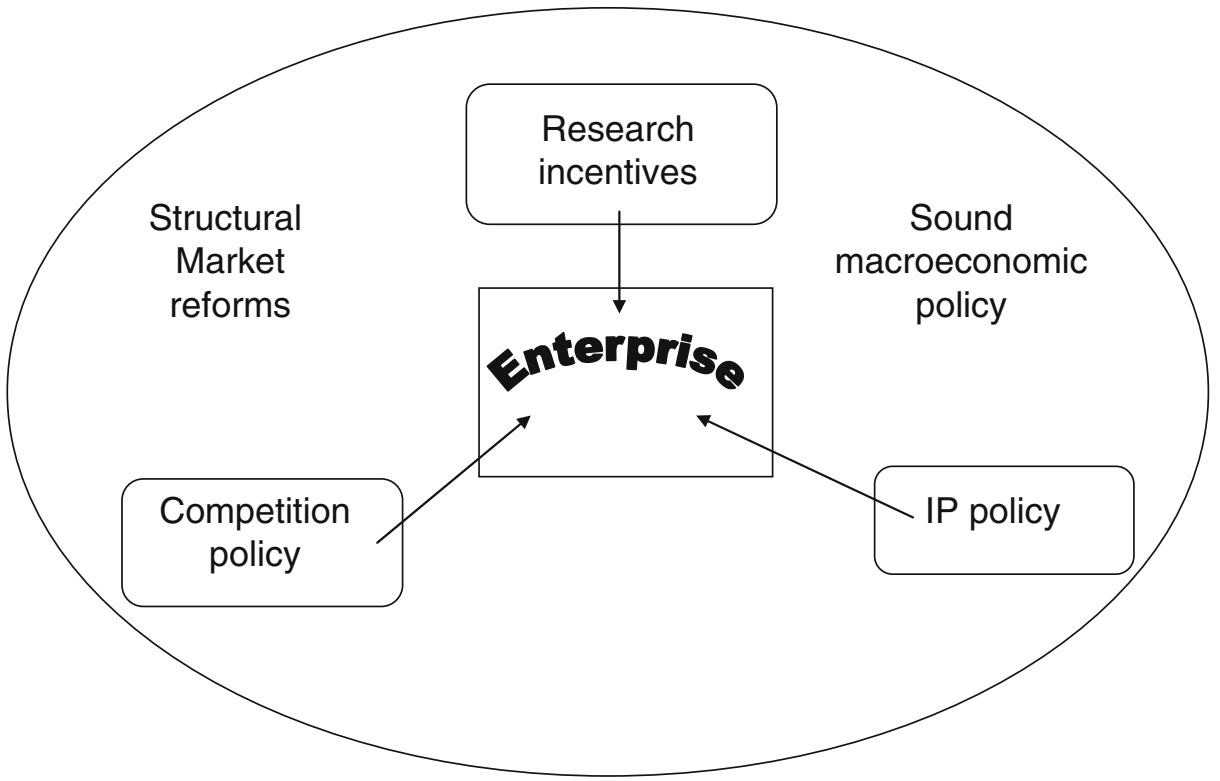

Fig. 2 Policies impacting on firm performance

productive system: a decline of competitiveness, weakness and dispersion of research and development, fragmentation of the common market, regulatory obstacles to the integration of the common market etc. J. Delors' strong point was to advance by means of what was formally the simplest and least engaging, that is to say the concrete realization of a large domestic market. The Single market initiative presents all the appearances of a balanced compromise. It satisfied the different proponents of liberalization by incorporating a plan to suppress the physical, technical and fiscal barriers, with the intention to help create a large domestic market. It also satisfied the aspirations of the proponents of community reinforcement through the extension of the majority law. It solemnly affirmed Europe's political vocation by multiplying common policies. In terms of economics, the line was thus drawn: the European revival should have necessarily consisted of two points: the one voluntarist, based on the promotion of a European industrial basis via high tech ventures such as Esprit, Eureka, Brite, Race, Euram, and the other more institutional, aimed to favor the creation of a true single market, such as the guidelines used to institute the large European domestic market. The dual project of expansion and liberalization necessitated the invention and implementation of financial and legal tools of a set of industrial policies (normally alternative) which European reformers wished to combine. The more interventions that industrial, research and technology policies required in the market to inflect its logics, the more interventions that competition and commercial liberalization policies needed to ease market access. ${ }^{11}$

Indeed, there is a strong imbalance between, on the one hand, the policies that are brought forth by the market and regulated by the law such as competition, integration or trade policies, which, while they require a strong initial policy-based initiative, they later manage themselves as if on autopilot (see Fig. 2). And, on the other hand, voluntarist industrial and technological policies that also demand continuous attention, but that are susceptible to

\footnotetext{
$\overline{{ }^{11} \text { See Cohen and Lorenzi (2001). }}$ 
reconsiderations at each cyclical downturn, and which therefore, in its duration, always run the risk of being questioned. Regardless of the fact that, directive after directive, "objective 1993" was implemented, and the non-tariff obstacles to trade were suppressed, we are obliged to admit that in terms of cooperative technological or industrial matters, Europe has not advanced at the same pace. An evident disequilibrium was established between market policies and promotional policies of the industrial sector.

In France, the signing of the Treaty of Maastricht led to believe that high-tech Colbertism could be exportable for two reasons: (1) because an entire chapter is dedicated to industrial policy and (2) because Europeans seemed to be closer to a French vision of industrial policy due to a HDTV project, Eureka 95. This project combined multiple facets: a normative component due to the implementation of a HDTV European norm, an industrial component consisting in help given to European champions for the acquisition of new equipment, a cultural facet due to the adoption of a device to help the creation of HDTV programs, and a distribution factor thanks to the financial assistance for the fabrication and dissemination of programs with the new norm. But this illusion did not even last as long as the time it took to implement the treaty.

In fact, with the SEA and the Euro, Europe has converted to horizontal competition policies. The programs initiated during the Davignon era were meant to help structure the European supply side policy and it's orientation towards new technologies. But instead their ambitions were reduced to simple research-based cooperation and the formation of a European scientific community, before being captured by the incumbents of redistribution policies, who wished to build upon less developed countries and less endowed businesses SME's. The Community was incapable of reaching its objectives, as it was a prisoner to the rules of competition, the mutual barter of favors and of consideration for cohesion and regional policies. In the rare areas where industrial Europe made advances, the Community was absent: Airbus, Ariane, etc... In the cooperative programs such as Eureka, the intergovernmental projects were more successful in the early stages, despite the fact that the initial labeling and support of the projects later fell victim to strict budgetary control policies. This example demonstrates that a policy once considered necessary by all sides, the bottom-up approach which was welcomed by all, and which could boast of incontestable successes (Jessi), is today concretely abandoned. This is due to Germany's lack of interest, which is in turn due to the fact that the focus on SME's does not erase the difficulties caused by the member countries' heterogeneity of legal regimes.

The horizontal industrial policies, of which one must mention the macro-economic policies of competitive disinflation and the promotional policies of competition within the framework of a single market didn't fare better than targeted sectoral policies. The combination of these different sets of policies didn't have the anticipated effects in terms of industrial specialization. At the end of the period, Europe discovered itself again lagging behind the USA in terms of growth, productivity, output, innovation, patents. ${ }^{12}$

There are several reasons for the failure of active industrial policies. The Treaty of Rome assigned a fundamental mission to the Commission: to construct an integrated market, to abolish borders and to eliminate all obstacles to economic integration. From this perspective, one can say that competition policies have a quasi-constitutional status. The Commission defends the interests of the consumer while adapting the global movement towards economic liberalization to the community space. It does this by pursuing the abuses of dominant positions by large firms and by liberalizing sheltered sectors. In short, the European policy project has always been well served by economic integration. This technique of integration

${ }^{12}$ Sapir (2004). 
through norms and regulations poses other problems: by privileging negative integration, the European market is loosing necessary flexibility and possibilities of rapid reorientation. When one compare integration and competition policies it becomes clear that Europe is more rigorous than the USA, due to its legislation on concentration, the Commission was successfully made the major player in designing the European market. The demise of operations such as Tetra-Sidel, Legrand-Schneider, Volvo-Scania, GE-Honeywell illustrates the doctrine that was progressively formed.

1. The Commission, by its definition of a relevant market, has the tendency to choose the national market as the reference market, and to define the concerned economic activities in restrictive terms. It is in this manner that the Commission refused the Scania-Volvo alliance: bringing forth excessive market share on the Nordic markets and not on the European domestic market.

2. The Commission uses integration policies as a competitive weapon. As opposed to the USA, here the potential non-competitive aspects of integration are appraised a priori.

3. The Commission refuses all consideration of industrial policies, remaining unmoved by the idea of a European public interest in the name of consumer defense. It was not taken into account, for example, that the veto of the Schneider-Legrand coalition actually deprives Europe of a leader in mid and low electric tensions, and weakened the two European firms.

By banning active sectoral industrial policies and by promoting competitive environment policies and sound macroeconomic orientations as key enhancers of growth the European Commission took a great risk. When European leaders convened in Lisboa to design a new agenda for growth, it was obvious that these policies have failed.

\section{The new French industrial policy}

Since 1984 and during the 1980s and the 1990s French economic policy can be summarized as a "dirigist end to dirigisme." Due to the new economic conditions prevailing since the SEA and the Maastricht Treaty and WTO agreements, France has to relinquish its interventionist arms and especially its vertically integrated industrial policies. The new name of the game was competitive horizontal policies, end of the "grand projects," globalization of former French national champions, dismantling of the Ministry of Industry. Two major policies took center stage during this period: the deregulation of the big utilities which were at the heart of the French colbertist model and the privatization of state owned firms. One of the direct effect of these policies was to weaken considerably national ownership of national champions. On the 100 Billion Euros proceeds of the privatizations, 2/3 of the shares issued are now foreignly owned mainly by American pension funds. Forty-six percent of the market capitalization of the CAC 40 is owned today by foreign investors. France which is portrayed in old books as a state led market economy or even as a dirigist economy is the most open major European economy in terms of capital control. ${ }^{13}$

In 2004 a sudden awakening of French political leaders took place: a new consensus favorable to active industrial policies emerged based on three types of arguments. On the one hand, the accelerated destruction of industrial jobs gave some credit to the "delocalization" threat. On the other hand, due to some major disputes (as seen in the Alstom case), the EU was

\footnotetext{
${ }^{13}$ Chaney and Guzzo (2006). 
less and less regarded as having solutions and progressively seen as an impediment to industrial restructuring. Lastly, the French political elites started to confront the inefficiencies of the human capital policies. They discovered the new scientific gap and the weak growth performance of innovating SME's. In France, a country stemming from the Jacobin tradition, problems of public action enter the national agenda after ritually designating prestigious personalities to write a report to the President. Thus, Jean Louis Beffa, chairman of St. Gobain, or Christian Blanc, prefect and former chairman of Air France, were selected as policy experts (see Fig. 3).

"Poles de compétitivité" or clusters, Industrial Innovation Agency, National research Agency, Oseo... In a few months, not only did France reverse its disengagement policy in industrial matters, and hence dismantled the State apparatus of intervention built after World War II, but it also reinvented a new industrial policy. After having ignored the problem of French industrial decline, the weakening of its capacity of innovation, and of the general fall of French science for nearly a decade, the political elites became more active and in their haste they adopted a large quantity of contradictory propositions.

For a country depicted as centralized and colbertist, the call for projects launched within the framework of the program "pôles de compétitivité" caused a strong local mobilization: elected officials and academics framed a few hundred projects, all aspiring to obtain the

\begin{tabular}{|c|c|c|c|c|c|}
\hline & $\begin{array}{l}\text { Clusters or Pôles de } \\
\text { competitivite }\end{array}$ & Technology Projects & SME policy & $\begin{array}{l}\text { Building a knowledge } \\
\text { economy }\end{array}$ & $\begin{array}{l}\text { Invesiting in Human } \\
\text { capital }\end{array}$ \\
\hline Logic of action & Territorial aggregation & Sectoral specialisation & Ecology of firms & |nstitutional design & $\begin{array}{c}\text { Improving efficiency } \\
\text { of universities }\end{array}$ \\
\hline Key institution & $\begin{array}{l}\text { CIADT \& adhoc } \\
\text { governing bodies }\end{array}$ & $\begin{array}{l}\text { Agence d"Innovation } \\
\text { Industrielle }\end{array}$ & Oseo (BDPME+Anvar) & $\begin{array}{l}\text { Agence Nle de la } \\
\text { Recherche }\end{array}$ & $\begin{array}{l}\text { Ministry of higher } \\
\text { Education } \\
\text { PRES, } \\
\text { Ag;Evaluation }\end{array}$ \\
\hline Financial incentive & $\begin{array}{l}500 \text { mio€ per year } \\
\text { (grants tax relief } \\
\text {..) }\end{array}$ & $\begin{array}{l}1 \text { b€ of public } \\
\text { endowment } \\
\text { PPI }\end{array}$ & Scarce resources & $\begin{array}{l}\text { 350mio€ } \\
2010 \text { Lisbon objective }\end{array}$ & Scarce resources \\
\hline Theoretical base & $\begin{array}{l}\text { Agglomeration effects } \\
\text { new economic } \\
\text { geography }\end{array}$ & $\begin{array}{l}\text { Evolutionary approach, } \\
\text { path dependancy }\end{array}$ & $\begin{array}{c}\text { Neo-classic economy } \\
\text { (market access) }\end{array}$ & $\begin{array}{l}\text { Schumpeterian growth } \\
\text { theory }\end{array}$ & \\
\hline Policy Document & Blanc Report & Beffa Report & Denis Report & Aghion/Cohen & $\begin{array}{l}\text { Assises de la } \\
\text { Recherche }\end{array}$ \\
\hline
\end{tabular}

Fig. 3 New French industrial policy 
label "pole de compétitivité." How are we to understand this enthusiasm in spite of the many contradictory initiatives? The concept of "pole de compétitivité" rests on a territorial logic: its main purpose is coordination of researchers and industrialists, professors and local authorities, bankers and civil servants on a local basis. All these actors are already there, but they often ignore each other in what they are doing. This idea of local productive systems, or "innovation ecosystems" as Christian Blanc branded them, was developed in different reports. Public authorities can correct the lack of coordination and promote aggregation effects on a territorial basis. This policy not only can rely on local support and political will but also on well documented research work. ${ }^{14}$

The logic of the new "grands projets" promoted by the new "Agence Industrielle pour l'Innovation" is sectoral specialization. The purpose is to find and promote the "Airbus" of tomorrow in fields such as energy, multimedia networks, clean motors, degenerative diseases...The idea is to reinvent the magic of high tech colbertism but in a different setting. Basically, J. L. Beffa is convinced that it is only by sticking to the national model that France can build its future strengths. ${ }^{15}$ He relies heavily on the academic work of Robert Boyer regarding "path dependency": France cannot import the cluster-Nasdaq model but it can rely on precious assets like its former national champions, its public research facilities, or its dedicated civil service. ${ }^{16}$

The creation of a National Agency of Research (ANR) obeys another logic, an institutional one. The problem this institution addresses is completely different from the previous ones. In order to stimulate scientific production, technological transfers, and innovation, without reforming the higher education and research systems, the government decided to create a new agency modeled after the American NSF. It is based on grants. It is bottom up driven, and based on peer review assessments. This idea that was defended with Aghion et al. (2006) presumed that France no longer has to support top down initiatives, vertically integrated scientific public institutions, or even egalitarian wage policies. When an economy is near the technology frontier it's innovation policies and nor imitation policies which matter and in order to achieve that goal, one need to build proper institutions. ${ }^{17}$

Finally the Oseo initiative obeys a fourth logic of intervention, one we can call an "ecology of firms" perspective: how to cure SME's, and more specifically high tech SME's,

\footnotetext{
${ }^{14}$ Cf Florida (1995), Storper (1995) in EIB 2006 op cit.

${ }^{15}$ Main theses of the Beffa Report (2005).

- Restart "great programs," as in the years 1960 and 1970. Cofinanced by the State and by great "pilot" firms, involving a network of SME's, they will make it possible to build poles of competences in industries of the future.

- This new model corresponds, according to Beffa and Boyer, with the French genius. Since Colbert, France knew to marry the State, its «grands corps» and the «national champions». "Let us stop believe naively in the only virtues of the market, start again to do what we knew well to do in the past and which should not have given up" Robert Boyer.

- The State is no more the benevolent tyrant but the catalyst": its assistance will make it possible for the industrial groups to work on risky long term projects, there is no need to use procurement policies of the past.

- In high tech fields the firm is not better informed than a state agency, so the argument of «picking the winners» is not valid, and in any case the report propose a collaborative strategy.

- There is a lack of finance for risky and costly technological ventures as the cases of airbus and TGV show us. If we don't help firms to invest in risky ventures their shareholders won't permit them to commit Rapport Beffa (15 Janvier 2005).

${ }^{16}$ Amable et al. (1997).

${ }^{17}$ Aghion and Cohen (2004).

炟 Springer
} 
absence of growth? From Scarpetta's work, one knows that the creation of companies in Europe is as dynamic as it is in the USA and the rate of mortality is not significantly higher. But due to a lack of finance or to market access problems or to regulatory hurdles these emergent companies don't grow enough. ${ }^{18}$ By combining BDPME and ANVAR and merging them into Oseo, the idea was to build the foundation of a French Small Business Administration.

Despite the fact that every report written for the President by renowned experts insisted on the need for choosing a logic, and sticking to it so as to avoid the wasting of scarce public resources, the French government decided to support everything! Each report justified the creation of a new institution with it's own budget and it's constituency. The main idea behind the new policy was to resolve problems of coordination arising because of the diversity of actors involved in each project and the fragmentation of European, national and local policy systems. With the creation of a whole set of new institutions, new problems of coordination arise.

Let us stop here to consider the "pôles de competitivité." This policy was designed to foster strategic collaboration on a territorial basis between companies, research centers and universities. The idea was to unleash the innovation potential and the industrial synergies of scattered small units by building partnerships around joint innovative projects. Ceramics in Limousin, optics in Essonne, IT in Brittany, aeronautics Space-Defense in Aquitaine... these are some examples of the hundreds of projects born within the span of a few weeks. Sixtyseven clusters were labeled "Pôles de competitivité" in 2005, of which six are international, nine national and the others local. Can this cluster policy, which is initiated by the French state but managed by local community development bodies, actually succeed? Four elements lead to a doubtful answer. The tender process gave very heterogeneous answers. Each local political authority wanted its own "pole," built around specific assets of unequal quality. The involvement of local authorities developed a parochial logic. The management of the whole process by Datar, an agency for regional development, had a perverse effect. This administration is in fact poorly equipped in human capital, industrial expertise and management capabilities. Also, the meager budget devoted to the whole project is an indication of the low priority given to this policy ( 750 Million Euros over 3 years decided in 2005 and then doubled in 2006). Last but not least, the risk of spreading scarce money is serious. Elected officials will exert strong pressure on a weak central administration to spread the "benefits" of public money. In fact certain projects are not only eligible to the "pôles de compétitivité" procedure but also to the AII and the ANR!

By giving up its policy of "grand projects," by multiplying vertical actions in favor of human capital, innovation, competitiveness, better regulation and while trying to consolidate the activity of certain industrial sectors by means of horizontal coordination, France seems to adopt the new matrix form of EU's industrial policy. This vision would be doubly inadequate because neither the Union, nor France are committed to any serious action of promotion of industrial specialization. The EU through the industrial policy always pursued other goals, R\&D promotion, domestic market construction, consumer protection, defense of environment, promotion of the "new economy." The great European successes do not owe much to the initiative of the Commission. Today the EU more modestly tries to avoid handicapping the manufacturing sector by imposing penalizing regulations. France in fact abandoned a model which proved reliable, the "grand projects" one, and tries a very widespread model, the

${ }^{18}$ Bartelsman et al. (2003). 
cluster one, but which does not fit to its political culture. The American "clusters" or the Italian "districts" are born from a local initiative and are carried by local actors, their success were very progressive. Coordination, co-operation, specialization are the key ingredients. The French clusters have a statistic origin, they are financed mainly by the state but they are managed locally.

\section{Conclusions}

The "new industrial policy" will quickly reveal its limits, its inconsistencies and its flawed design. National policies are left little space between a policy of "great technological projects," which typically applies to Europe, and a policy of "clusters," which requires local responsibility. The design and implementation of an adequate structure of incentives is in the political realm of the nation state, but budgetary constraints on the one hand and political difficulties in reforming fiscal and social systems on the other, gradually condemn the government to impotence.

From this perspective, it is necessary to take note of the end of "high tech colbertism" and to radically doubt the chances of success of those projects from the "Agency of Industrial Innovation" as wanted by Jean Louis Beffa. This structure is unsuitable for at least three reasons: its scope (France essentially), its strategy (to invent a new specialization strategy within the framework of a public-private partnership), and its governance (which risks a conflict of interest). ${ }^{19}$

Does this conclusion lead us to forego any action on specialization? In fact, this is not the case of policies of competitive environment aiming at improving the attractiveness of a site (infrastructures of research, fiscal and legal incentives for innovation) but which, in fact, tend to promote such type of activities rather than others such as biotech, digital industries, optics etc.. Horizontal policies and vertical policies are very often opposed in the economic literature. In fact, the cluster policy illustrates the effects on specialization whereas they are, by destination, territorialized policies of competitive environment.

Is it therefore necessary to consider competition policies as in contradiction with industrial policies? The defense of consumer interests is not necessarily incompatible with the reinforcement of the European groups in the world competition. Whether the European Commission authorizes or not the merger of European groups in the utilities sector, for example, may have a tremendous effect on European industry in a globalized world, where the other members are playing by different rules (railways, air transport, telecom, energy, water). One can indeed combine European and national competition policies without seeking an atomistic competition. In a recent past, policies of standardization and of innovative uses promotion had a tremendous success with the GSM or the electronic money. These lessons were obviously forgotten when the European Commission designed its roll out plan for $3 \mathrm{G}$ mobile telephony: tax competition and uncoordinated tender processes for spectrum allocation of frequencies effectively altered the European competitive advantage in mobile telephony.

Lastly, even strategic trade policies can contribute to industrial policy, as the case of Airbus demonstrates: even in the context of the WTO, when global competition is at risk, state intervention is the best antidote to a world monopoly. Thus the end of the sectoral-targeted policies will not have been the last word of policies of promotion of the industrial activity.

${ }^{19}$ One of the key projects of AII-Quaero-based upon a cooperation between French and German companies and research institutes have already failed. 


\section{References}

Aghion, Ph. and Cohen, E., "Education et Croissance," Rapport au CAE, La Documentation Française Paris, 2004.

Aghion, Ph., Cohen, E., and Pisani-Ferry, J., Politique Economique et Croissance en Europe. CAE La DF: Paris, 2006.

Amable, B., Barré, R. and Boyer, R. "Les Systèmes d'Innovation à 1'Ere de la Globalisation," Economica, 1997.

Bartelsman, E., Scarpetta, St., and Schivardi, F. Comparative analysis of firm demographics and survival: Micro-level evidence for the OECD countries. Economics Department Working Papers no. 348, 2003.

Beffa Report. Rapport Beffa Pour une nouvelle Politique industrielle Paris, 15 Janvier 2005, mimeo, 2005.

Chaney, E. and Guzzo, L. OPA: le protectionnisme franchira-t-il la barriere des éspèces. http://www.telos-eu. com/2006/03/opa le protectionnisme franchi.php, 2006.

Cohen, E., L'Etat brancardier. Calmann Levy: Paris, 1989.

Cohen, E., Le colbertisme high-tech. Économie du grand projet. Hachette Pluriel: Paris, 1992.

Cohen, E. An Industrial policy for Europe? "Theoretical Foundations of Industrial Policy," EIB Papers, Vol 11 No. 1, 2006.

Cohen, E. and Bauer M. Le Grandes manoeuvres industrielles. Belfond: Paris, 1985.

Cohen, E. and Lorenzi, J. H. CAE Politiques européennes pour l'industrie La DF, 2001.

Florida, R., "Toward the learning region," Futures, vol. 27, no. 5, pp. 527-536, 1995.

Richonnier, M. Les métamorphoses de l'Europe de 1769 à 2001, Paris, Flammarion, Enjeux pour demain, 1985.

Rodrik, D., Industrial policy for the XXIst century. Harvard Univerity: Cambridge, MA, 2004.

Sapir, A., An Agenda For a Growing Europe, The sapir report. University Press: Oxford, 2004.

Seabright, P. "National and European champions_-burden or blessing," CESIfo, Vol. 6:2, pp. 52-57, 2005.

Storper, M., "The resurgence of regional economies, ten years later," European Urban and Regional Studies, vol. 2 , no. 3, pp. 191-221, 1995 . 